\title{
A re-examination of the molecular systematics and phylogeography of taxa of the Peromyscus aztecus species group, with comments on the distribution of $P$. winkelmanni
}

\author{
C. William Kilpatrick ${ }^{1 *}$, Nelish Pradhan ${ }^{2}$, and Ryan W. NorRis ${ }^{3}$ \\ ${ }^{1}$ Department of Biology, University of Vermont, Burlington, 05405-0086, Vermont, USA. Email: wkilpatr@uvm.edu (CWK). \\ ${ }^{2} \mathrm{CIBIO} / \mathrm{InBIO}$, Research Center in Biodiversity and Genetic Resources, University of Porto, Quintas 7, 4485-661 Vairäo, Portugal. \\ Email:npradhan@cibio.up.pt (NP). \\ ${ }^{3}$ Department of Evolution, Ecology and Organismal Biology, The Ohio State University at Lima, Lima, 45804, Ohio, USA. Email: \\ ryanwnorris@gmail.com (RWN). \\ * Corresponding author
}

The objectives of this study are to examine the available molecular data from the mitochondrial cytochrome- $b$ gene (Cytb) and a concatenated dataset with this gene and two nuclear introns (Adh-1-12 and Fgb-17) to reexamine the systematic and phylogeographic conclusions reached by Sullivan et al. (1997) concerning the Peromyscus aztecus species group. The divergence of samples of $P$. aztecus oaxacensis across the Isthmus of Tehuantepec are further examined and taxonomic revisions are suggested. In addition, this study reviews the sources of data that lead to the conclusion that $P$. winkelmanni occurred in the Sierra Madre del Sur in Guerrero including a morphometric examination of a reported voucher. Bayesian and maximum likelihood analyses were conducted on a dataset of 31 Cytb sequences of all taxa in the $P$. aztecus group except for $P$. a. cordillerae and a concatenated dataset including five individuals of this group. Representative taxa of the $P$. boylii, $P$. mexicanus, and $P$. truei groups were included in both analyses. Body and cranial measurements of the voucher of the $P$. winkelmanni from Guerrero from which a Cytb sequence is reported to have been obtained was compared with measurements from specimens taken from the vicinity of Dos Aguas, Michoacán, including the type locality. We identified seven instances involving problematic identifications in GenBank. Once these issues were addressed, well-supported monophyletic sister clades of the $P$. aztecus and $P$. boylii species groups were recovered from phylogenetic analyses of Cytb sequences (Fig 1). Phylogenetic analyses of the Cytb and the concatenated datasets recover similar topologies that support the relationships of taxa of the aztecus group proposed by an earlier molecular study. Populations of $P$. $a$. oaxacensis southeast of the Isthmus of Tehuantepec represent a distinct species. Measurements of the voucher from Guerrero identified as the source of a $P$. winkelmanni Cytb sequence are smaller than P. winkelmanni for several characters. The divergent populations of $P$. $a$. oaxacensis from southeast of the Isthmus of Tehuantepec are recognized as two subspecies of $P$. cordillerae, $P$. c. cordillerae and $P$. c. hondurensis, whereas those northwest of the Isthmus are retained as $P$. $a$. oaxacensis. The lack of genetic divergence observed between $P$. $a$. evides and $P$. $a$. oaxacensis questions whether these two taxa should continue to be recognized as separate subspecies. Northern and southern populations of $P$. spicilegus demonstrate moderate divergence and additional examination of morphological and molecular differentiation within this taxon is warranted. The distribution of $P$. winkelmanni should be restricted to the vicinity of Dos Aguas, Michoacán, due to the lack of a voucher specimen that would confirm its reported occurrence in Guerrero.

Los objetivos de este estudio son examinar los datos moleculares disponibles del gen del mitocondrial citocromo-b (Cytb) y un conjunto de datos concatenados con este gen y dos intrones nucleares (Adh-1-I2 y Fgb-17) para reexaminar las conclusiones sistemáticas y filogeográficas alcanzadas por Sullivan et al. (1997) sobre el grupo de especies de Peromyscus aztecus. Se examina más a fondo la divergencia de muestras de $P$. aztecus oaxacensis a lo largo del Istmo de Tehuantepec y se sugieren revisiones taxonómicas. Este estudio revisa las fuentes de datos que llevan a la conclusión de que $P$. winkelmanni se distribuye en la Sierra Madre del Sur de Guerrero, incluyendo un examen morfométrico de los ejemplares "voucher". Se realizaron análisis bayesianos y de máxima verosimilitud de 31 secuencias de Cytb de todos los taxa en el grupo de $P$. aztecus, excepto P. a. cordillerae, y un conjunto de datos concatenados que incluye cinco individuos de este grupo. En ambos análisis se incluyeron ejemplares representativos de los grupos P. boylii, P. mexicanus y P. truei. Las medidas somáticas y craneales de los ejemplares "voucher" de $P$. winkelmanni de Guerrero, de los que se obtuvo una secuencia de Cytb, se compararon con medidas de especímenes tomados en las cercanías de Dos Aguas, Michoacán, incluyendo la localidad tipo. Se detectaron siete casos que involucran identificaciones problemáticas en GenBank. Una vez que se abordaron estos problemas, se recuperaron los clados monofiléticos hermanos con buen soporte de los grupos de especies de $P$. aztecus y P. boylii a partir de análisis filogenéticos de secuencias de Cytb. Los análisis filogenéticos de Cytb y los conjuntos de datos concatenados recuperan topologías similares que apoyan las relaciones entre taxa del grupo aztecus propuesto por un estudio molecular anterior. La población de P. a. oaxacensis al sureste del Istmo de Tehuantepec representan una especie distinta. Las medidas de los "vouchers" de Guerrero identificado con secuencia Cytb como $P$. winkelmanni son más pequeñas que las de $P$. winkelmanni para varios caracteres. Las poblaciones divergentes de P. a. oaxacensis del sureste del Istmo de Tehuantepec se reconocen como dos subespecies de $P$. cordillerae, $P$. c. cordillerae y $P$. $c$. hondurensis, mientras que los del noroeste del istmo se conservan como $P$. $a$. oaxacensis. La falta de divergencia genética observada entre $P$. $a$. evides y P. a. oaxacensis cuestiona si estos dos taxones deberían seguir siendo reconocidos como subespecies independientes. Las poblaciones del norte y del sur de P. spicilegus demuestran una divergencia moderada y se justifica un examen adicional de la diferenciación morfológica y molecular dentro de este taxón. La distribución de P. winkelmanni debería estar restringida a las cercanías de Dos Aguas, Michoacán, debido a la falta de "vouches" que confirmara su distribución reportada en Guerrero.

Keywords: Isthmus of Tehuantepec; Peromyscus cordillerae; P. aztecus oaxacensis; P. winkelmanni. 


\section{Introduction}

The Peromyscus aztecus group was first recognized by Carleton (1989) with a content of three distinct species: $P$. aztecus (Saussure, 1860); P. spicilegus Allen, 1897; and P. winkelmanni Carleton, 1977. Five montane subspecies have been recognized within $P$. aztecus by Carleton $(1979,1989)$ : P. a. aztecus occurring in the Sierra Madre Oriental; P. a. cordillerae Dickey, 1928, occurring in the highlands of Mt Cacahuatique of El Salvador; P. a. evides Osgood, 1904 (including the synonym yautepecus Goodwin, 1955); occurring in the Sierra Madre del Sur; P. a. hylocetes Merriam, 1898, occurring in the Transmexican Volcanic Belt; and P. a. oaxacensis Merriam, 1898, occurring in the highlands of central Oaxaca in the Sierra Madre del Sur, across the Isthmus of Tehuantepec in the Tierras Altas de Chiapas, and south to Guatemala, Honduras, and El Salvador. The divergence and phylogenetic relationships among and within the taxa of the $P$. aztecus species group have been characterized and estimated by examination of cranial morphology (Carleton 1977, 1979; Bradley et al. 1996), glans and bacular morphology (Bradley and Schmidly 1987; Bradley et al. 1989, 1990), karyotypes (Carleton et al. 1982; Smith et al. 1989; Smith 1990), allozymes (Sullivan and Kilpatrick 1991) and cytochrome-b (Cytb) sequences (Sullivan et al. 1997).

Carleton (1977) reported that P. winkelmanni occurs in the oak-pine forest at elevations between 6,900 and 8,000 feet from three localities SE and WSW of Dos Aguas in Michoacán. In a karyotypic study, Smith et al. (1989) reported a specimen from the vicinity of Filo de Caballos in Guerrero which expanded the range of $P$. winkelmanni from the mountains of the Sierra Madre del Sur in southwestern Michoacán to the main portion of the Sierra Madre del Sur in Guerrero. The occurrence of $P$. winkelmanni in the Sierra de Coalcomán in Michoacán and the Sierra Madre del Sur in Guerrero areas separated by a deep canyon of the Rio Balsas was viewed as biogeographically implausible by Musser and Carleton (2005). They concluded that the identification of the vouchers of $P$. winkelmanni from Guerrero needed to be reconfirmed.

The gleaning mouse, P. spicilegus, occurs in western México along the flanks of Sierra Madre Occidental from Sinaloa and Durango to Jalisco and northern Michoacán in the western Transmexican Volcanic Belt (Carleton 1977, 1989; Bradley et al. 1996). Fixed differences were observed in allozyme data reported by Sullivan and Kilpatrick (1991) from $P$. spicilegus suggesting that samples from Michoacán and samples from Nayarit possibly represent different species. Although considerable morphological (Bradley et al. 1996) and chromosomal (Carleton et al. 1982; Smith et al. 1989; Smith 1990) variation has been reported for this taxon, no geographic pattern of that variation has been detected. Sequence analysis by Sullivan et al. (1997) only examined samples from the southern portion of the range of this species, leaving the question of the sequence differentiation between northern and southern populations unaddressed.
A cladistic analysis by Sullivan and Kilpatrick (1991) including allozyme data, chromosomal characters reported by Smith et al. (1989) and morphological characters from Bradley et al. (1990) demonstrated considerable differentiation between hylocetes and other subspecies (aztecus, evides, and oaxacensis) of $P$. aztecus. The level of genetic identity and the degree of allozymic, chromosomal and morphological divergence exhibited by hylocetes led Sullivan and Kilpatrick (1991) to conclude that this taxon should be reinstated as a species, P. hylocetes. Analyses of Cytb sequence data supported this conclusion and found substantial levels of genetic divergence between $P$. hylocetes and P. aztecus (Sullivan et al. 1997).

The molecular analysis of Sullivan et al. (1997) recovered $P$. a. oaxacensis as polyphyletic and they suggested that populations south and east of the Isthmus of Tehuantepec represented a distinct species that was strongly divergent from populations of P. a. oaxacensis in Oaxaca. Musser and Carleton (2005) noted that populations of P. aztecus occupying the highlands south of the Isthmus of Tehuantepec warrant further scrutiny but continued to recognize them as subspecies of $P$. aztecus, $P$. a. oaxacensis. Duplechin and Bradley (2014) recognized oaxacensis populations in México as a distinct species citing the genetic data and inferences of Sullivan et al. (1997) but stated that it was unclear whether populations in Oaxaca were referable to $P$. a. aztecus, P. a. evides, or P. oaxacensis. Bradley et al. (2017) recognized populations northwest and southeast of the Isthmus of Tehuantepec as $P$. oaxacensis without comment on the genetic differentiation of populations separated by this geographic feature.

Although considerable morphological variation has been observed among allopatric populations of $P$. aztecus that has warranted the recognition of subspecies (Carleton 1977, 1979, 1989), little genetic differentiation has been observed (Sullivan and Kilpatrick 1991; Sullivan et al. 1997) other than between populations northwest and southeast of the Isthmus of Tehuantepec. Qualitative data of glans and bacular morphology (Bradley and Schmidly 1987; Bradley et al. 1990) showed a close relationship of aztecus to oaxacensis and evides to hylocetes, whereas quantitative data depicted aztecus as being distinct from the other subspecies (Bradley et al. 1990). Phenetic analysis of allozymic data (Sullivan and Kilpatrick 1991) found that evides clustered with oaxacensis to the exclusion of aztecus. However, analyses of allozymic data (Sullivan and Kilpatrick 1991) and Cytb sequence data (Sullivan et al. 1997) recovered evides and oaxacensis in the same cluster or clade with aztecus in a separate cluster or a sister clade. The lack of congruence among datasets makes it difficult to resolve the relationships among the subspecies of $P$. aztecus.

Since the initial molecular systematic analyses of the $P$. aztecus group by Sullivan et al. (1997), mitochondrial and nuclear sequence data have been obtained from 15 additional specimens from this group. The objectives of this study are to analyze an expanded dataset of Cytb sequences 
and a concatenated dataset of mitochondrial (Cytb) and nuclear (Adh-1-12 and Fgb-17) markers to further resolve the phylogeography and phylogenetic relationships among the taxa of this group. Specifically, these analyses will address: 1) the differentiation between northern and southern populations of $P$. spicilegus; 2 ) The differentiation between $P$. hylocetes and subspecies of $P$. aztecus; 3 ) The differentiation and relationships of populations recognized as $P$. a. oaxacensis separated by the Isthmus of Tehuantepec; and 4) the relationships among subspecies of $P$. aztecus. Additionally, this paper examines the voucher of a specimen from which tissue and a karyotype were reported to have been obtained that led to the conclusion of Smith et al. (1989) and that was supported by Sullivan et al. (1997) that $P$. winkelmanni occurs in the vicinity of Filo de Caballos in Guerrero.

\section{Materials and Methods}

Collection and analyses of molecular data. All available cytochrome $b(C y t b)$ sequences in GenBank (https://www. ncbi.nlm.nih.gov/genbank/) as of November 15, 2020, for taxa of the $P$. aztecus species group $(n=31)$; representative Cytb sequences from 9 taxa of its sister group, the $P$. boylii species group $(n=21)$; and two outgroup taxa from the $P$. truei species group (Table 1) were downloaded and aligned using ClustalW (Thompson et al. 1994) in MEGA7 (Kumar et al. 2016). After an initial Neighbor-Joining analysis (Saitou and Nei 1987) in MEGA7 and a Nucleotide Blast search of an outlying sequence, sequences from three taxa of the $P$. mexicanus species group were added to the Cytb dataset (Table 1). PartitionFinder 2.1.1 (Lanfear et al. 2016) was used to find the best partitioning scheme and the best model for each partition based on the AIC criterion under a likelihood framework using PhyML (Guindon et al. 2010) and the greedy algorithm (Lanfear et al. 2012). Maximum likelihood $(\mathrm{ML})$ analysis with 1,000 bootstrap replicates and $\mathrm{GTR}+\mathrm{I}+\mathrm{G}$ model on all partitions was conducted with RAxML ver. 8.0 (Stamatakis 2014). The majority-rule consensus tree (MRC) with bootstrap support values was constructed in Mesquite ver. 3.5 (Maddison and Maddison 2011). A Bayesian analysis was conducted on the CIPRES portal (https://www.phylo. org; Miller et al. 2010) using the partitions and models identified with PartitionFinder for the Cytb dataset in MrBayes 3.2.3 (Ronquist and Huelsenbeck 2003). Default settings with two simultaneous MCMC runs of $10,000,000$ generations with sampling every 1,000 generations were used and the log files for both runs were examined in Tracer 1.6 (Rambaut et al. 2014). A burn-in of 1,000,000 generations was set for each run and the runs were combined after discarding the burn-in to produce a MRC tree with posterior probabilities in Mesquite.

Kimura 2-parameter distances (=K2P; Kimura 1980) were estimated using MEGA7 based on Cytb alignments of individuals of the $P$. aztecus group in Table 1 . Individuals were generally grouped by clades recovered in the phylogenetic analyses to determine mean K2P distances. However, subspecies of $P$. aztecus samples from México were grouped by biogeographic areas (mountain ranges). These mean K2P values were used to examine species boundaries based on levels of interspecific divergence observed among rodents and other mammals (Bradley and Baker 2001).

Sequences for two nuclear introns, alcohol dehydrogenase intron 2 (Adh-1-I2) and beta-fibrinogen intron 7 (Fgb-17) were downloaded from GenBank for all available samples from the $P$. aztecus species group $(n=13)$, six taxa of the $P$. boylii species group, two taxa of the $P$. mexicanus species group and two taxa of the $P$. truei species group (Table 1). Sequences for these two nuclear introns were concatenated with a Cytb sequence obtained either from the same specimen or from a specimen from the proximity of the collecting locality of the nuclear sequence source (Table 1). A concatenated dataset of a Cytb and one or two nuclear genes was constructed for five samples reported to be from taxa of the $P$. aztecus group, nine samples from six taxa of the $P$. boylii group, and two samples from both the $P$. mexicanus and $P$. truei groups. Six additional samples represented by only Cytb sequences from $P$. a. oaxacensis from either side of the Isthmus of Tehuantepec were included in the analyses with concatenated sequences.

PartitionFinder 2.1.1 was used to find the best partitioning scheme and the best model for the concatenated dataset. A bootstrapped ML analysis was carried out for the concatenated dataset as with the Cytb dataset and the MRC tree with bootstrap support values was constructed in Mesquite. A Bayesian analysis was conducted on the CIPRES portal using the partitions and models identified with PartitionFinder for the concatenated dataset in MrBayes 3.2.3. The same parameters were used in this Bayesian analysis as used in the analysis of the Cytb dataset to produce a MRC tree with posterior probabilities in Mesquite.

Pairwise uncorrected $p$-values were estimated with MEGA7 for sequences of the two nuclear introns. These values were used to identify the species of the source of nuclear sequences from specimens determined as likely misidentified in the Cytb analysis, from different nonidentical sequences reported from the same specimen, and sequences reported from species well outside of their known range.

Morphometrics. External measurements (in $\mathrm{mm}$ ) including total length (TL), length of tail (LT), length of hind foot $(\mathrm{HF})$, and ear length (EL) were taken from the collectors' field tags. Head and body length (HB) was calculated by subtracting the tail length from the total length to provide comparable data for specimens with broken tails. Measurements were taken from specimens of $P$. winkelmanni collected from the following locations: Michoacán: $7.4 \mathrm{mi}$ WSW Dos Aguas $(n=10) ; 6.3 \mathrm{mi}$ WSW Dos Aguas $(n=3) ; 6.9 \mathrm{mi}$ WSW Dos Aguas $(n=3)$ housed in the Texas Cooperative Wildlife Collection (TCWC). Seven dimensions of the skull, following those reported by Carleton (1977) were measured $( \pm 0.01 \mathrm{~mm})$ with dial calipers including: skull greatest length $(\mathrm{SGL})$, rostral length $(\mathrm{RL})$, brain-case width $(\mathrm{BCW})$, zygomatic breadth (ZB), interorbital width (IOW), molar row length 


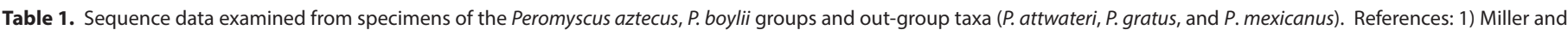

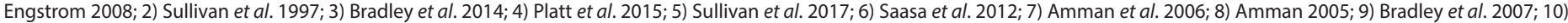

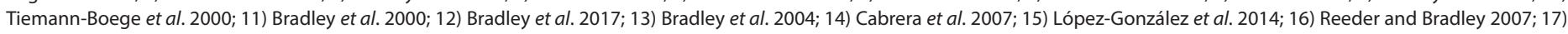
Durish et al. 2004; and 18) Bradley et al. 2016.

\begin{tabular}{|c|c|c|c|c|c|c|c|}
\hline \multirow[t]{2}{*}{ Taxon $^{1}$} & \multirow[t]{2}{*}{ State } & \multirow[t]{2}{*}{ Location } & \multicolumn{3}{|c|}{ GenBank Accession Number } & \multirow[t]{2}{*}{$\begin{array}{l}\text { Field or Catalog } \\
\text { Number }\end{array}$} & \multirow[t]{2}{*}{ Ref } \\
\hline & & & Cytb & Adh-1-12 & Fgb-I7 & & \\
\hline \multicolumn{8}{|c|}{ P. aztecus Species Group } \\
\hline \multirow[t]{4}{*}{ P. aztecus } & Michoacán & $5 \mathrm{~km}$ E Dos Aguas & FJ2146832 & & & FN 22401 & GenBank \\
\hline & Michoacán & $5 \mathrm{~km}$ E Dos Aguas & & FJ21466933 & FJ214695 & TK $45255^{4}$ & GenBank \\
\hline & El Salvador & $\begin{array}{l}\text { Santa Ana, Parque Nacional Montecristo, Los } \\
\text { Pines }\end{array}$ & EF989968 & & & ROM 101489 & 1 \\
\hline & El Salvador & Santa Ana, Parque Nacional Montecristo, Los Pines & EF989969 & & & ROM 101490 & 1 \\
\hline \multirow[t]{3}{*}{ P. a. aztecus } & Veracruz & Teocelo & U89966 & & & 2204 & 2 \\
\hline & Veracruz & Teocelo & U89967 & & & 235 & 2 \\
\hline & Veracruz & 8.8 km N Huatusco & U89968 & & & GK 4053 & 2 \\
\hline \multirow[t]{5}{*}{ P. a. evides } & Oaxaca & 5.6 km S. Suchixtepec & U89970 & & & GK 3439 & 2 \\
\hline & Oaxaca & 9.7 km E Juquila & U89969 & & & GK 3407 & 2 \\
\hline & Guerrero & 6.4 km SSW Filo de Caballos & FJ214685* & FJ214670* & FJ214700* & TK 93391 & $3,4,4$ \\
\hline & Guerrero & 4 mi SSW Filo de Caballos & KY707306 & & & TK 93385 & 5 \\
\hline & Guerrero & $17.22 \mathrm{~N} \times 99.28 \mathrm{~W}$ & AB703007 & & & $1950 / 171$ & 6 \\
\hline \multirow[t]{5}{*}{ P. a. oaxacensis } & Honduras & Francisco, Morazan, La Tigra Parquae Nacional & FJ214688*3 & FJ214675*3 & FJ214714*3 & TK 101037 & GenBank \\
\hline & Guatemala & Zacapa, 2 km N San Lorenzo & U89971 & & & 34194 & 2 \\
\hline & Guatemala & Alta Verapaz Yalijux Mountain, Chelemha Reserve & KF201657 & & & TK 151047 & 3 \\
\hline & Oaxaca & 1.4 km N Llano de las Flores & U89972 & & & GK 3516 & 2 \\
\hline & Oaxaca & 2.1 km S Llano de las Flores & U89973 & & & CWK 2117 & 2 \\
\hline \multirow[t]{6}{*}{ P. hylocetes } & Michoacán & Estacion Cerro Burro, Microodas, 3,270 m & DQ000481* & AY994235* & FJ214705* & TK 45309 & 3, 7, GenBank \\
\hline & Michoacán & Puerto Garnica & U89974 & & & CWK 2040 & 2 \\
\hline & Morelos & 2.43 km W Huitzilac & U89975 & & & GK 2781 & 2 \\
\hline & Michoacán & Puerto Garnica & U89976 & & & CWK 2035 & 2 \\
\hline & Michoacán & 3.6 km W Mil Cumbres & U89977 & & & GK 4229 & 2 \\
\hline & Michoacán & 4.9 km S Los Azufres & U89978 & & & GK 2853 & 2 \\
\hline \multirow[t]{7}{*}{ P. spicilegus } & Michoacán & Dos Aguas & & AY994233 & FJ214719 & TK 45262 & 8, GenBank \\
\hline & Michoacán & 5 km E Dos Aguas & & AY994234 & & TK $45255^{4}$ & 4 \\
\hline & Michoacán & Km 81 carr. Ario de Rosales and La Huacana & DQ000480* & AY994232* & & TK 47888 & 3,7 \\
\hline & Durango & San Juan de Camarones & AY322512 & & & TK 70912 & 3 \\
\hline & Durango & San Juan de Camarones & DQ973107 & & & TK 70919 & 9 \\
\hline & Michoacán & 10.7 km E Uruapan & U89979 & & & GK 4217 & 2 \\
\hline & Nayarit & 8.1 km W Villa Carranza & U89980 & & & GK 3253 & 2 \\
\hline \multirow[t]{4}{*}{ P. winkelmanni } & Michoacán & 6.9 mi WSW Dos Aguas & AF131930* & FJ214678* & FJ214721* & GK 3311 & 3, GenBank \\
\hline & Michoacán & 19.3 km WSW Dos Aguas & U89981 & & & GK 3287 & 2 \\
\hline & Michoacán & 19.3 km WSW Dos Aguas & U89982 & & & GK 3286 & 2 \\
\hline & Guerrero & Filo de Caballo & U89983 & & & GK 3388 & 2 \\
\hline \multicolumn{8}{|c|}{ P. boylii Species Group } \\
\hline \multirow[t]{2}{*}{ P. b. boylii } & California & Monterey Co., Hastings Natural History Reservation & AF155386* & & & MVZ: K, Nutt 120 & 9 \\
\hline & California & San Diego Co., Heise County Park & & AY994225* & & TK 90233 & 7 \\
\hline \multirow[t]{2}{*}{ P. b. rowleyi } & Jalisco & 30 km W Huejuquilla del Alto & AF155388* & & AY274208* & TK 48636 & 10,4 \\
\hline & Jalisco & 2 km NW Mesconcitos & & AY994227* & & TK 93089 & 4 \\
\hline \multirow[t]{3}{*}{ P. b. utahensis } & Utah & Garfield Co., Henry Mts., Mt. Pennell, Sidehill & AF155392* & & & MSB-NK 39457 & 9 \\
\hline & & Springs & & & & & \\
\hline & Utah & Washington Co., Beaver Dam Wash & & AY994226* & & TK 24389 & 8 \\
\hline P. beatae & Chiapas & Yalentay & & AY994223 & & TK 93279 & 7 \\
\hline
\end{tabular}


Table 1. Continuation...

\begin{tabular}{|c|c|c|c|c|c|c|c|}
\hline \multirow[t]{2}{*}{ Taxon ${ }^{1}$} & \multirow[t]{2}{*}{ State } & \multirow[t]{2}{*}{ Location } & \multicolumn{3}{|c|}{ GenBank Accession Number } & \multirow[t]{2}{*}{$\begin{array}{c}\text { Field or Catalog } \\
\text { Number }\end{array}$} & \multirow[t]{2}{*}{ Ref } \\
\hline & & & Cytb & Adh-1-12 & $F g b-17$ & & \\
\hline & Veracruz & Xometla & AF131921* & AY994222* & & GK 3954 & 3,8 \\
\hline & Veracruz & 6.7 km NE, 81.6 km SE Perote & & & FJ214696* & TK 150106 & GenBank \\
\hline & Oaxaca & 3 mi S Suchixtepec & AF131923 & & & GK 3450 & 11 \\
\hline & Chiapas & 12 km SE Ixtapa & AF131917 & & & FN 33058 & 11 \\
\hline \multirow[t]{3}{*}{ P. carletoni } & Nayarit & Ocota de la Sierra & KF201663 & & & TK 148445 & 3 \\
\hline & Nayarit & Ocota de la Sierra & KF201664 & & & TK148432 & 3 \\
\hline & Nayarit & Ocota de la Sierra & KF201671 & & & TK148428 & 3 \\
\hline \multirow[t]{3}{*}{ P. kilpatricki } & Michoacán & Km 81 between Ario de Rosales and La Huacana & KX523179 & & & TK 47887 & 12 \\
\hline & Michoacán & Km 81 between Ario de Rosales and La Huacana & KX523180 & & & TK 47890 & 12 \\
\hline & Michoacán & 13.5 km SW Zitacuro & KX523183 & & & Tk 150627 & 12 \\
\hline \multirow[t]{4}{*}{ P. levipes } & Michoacán & Las Minas, 3 km SW Tuxpan & DQ000477* & AY994224* & & TK 47819 & 7,7 \\
\hline & México & 12 km S Acambay & AY322509* & KT361507* & & TK 93400 & 13, GenBank \\
\hline & México & 14.1 km NW Villa del Carbon & KX523178* & & FJ214707* & TK 112532 & \\
\hline & & & & & & TK $113532^{*}$ & 12,4 \\
\hline P. I. ambiguus & Nuevo Léon & Cola de Caballo & AF131928 & & & GK 3840 & 3 \\
\hline P. I. levipes & Tlaxcala & 2 km W Teacalco & AF131929 & & & GK 4031 & 3 \\
\hline \multirow[t]{4}{*}{ P. schmidlyi } & Durango & 6.2 km W Coyotes, Hacienda Coyotes & AY370610* & AY994228* & FJ214718* & TK 72443 & 9, 7, GenBank \\
\hline & Durango & 30 km SW Ojitos & AY322524* & AY994229* & & TK 70812 & 13,8 \\
\hline & Sonora & $0.8 \mathrm{~km} \mathrm{~N}, 1.4$ km E Yecora & EU234540 & & & $10889 \mathrm{CIB}$ & 14 \\
\hline & Chihuahua & $3.2 \mathrm{~km} \mathrm{~S}, 0.8 \mathrm{~km}$ E Hueleyvo & KC403898 & & & CRD 4001 & 15 \\
\hline \multicolumn{8}{|c|}{ Out-Group Taxa } \\
\hline P. attwateri & Oklahoma & Mclntosh Co., 4.9 km E Dustin & AY155384* & AY817626* & AY $274207^{*}$ & TK 23396 & $9,7,16$ \\
\hline P. gratus & Michoacán & Aquililla, 4 km E Cuitzeo & AY376421* & AY994218* & FJ214703* & TK 46354 & $9,7,4$ \\
\hline P. mexicanus & Chiapas & 9 mi N Ocozocozulta & AY376425* & & AY274210* & TK 93314 & 17,16 \\
\hline P. nudipes & Nicaragua & Madriz, San Lucas, Los Mangos & FJ214687* & AY994238* & FJ214713* & TK 93600 & $4,4,4$ \\
\hline P. nicaraguae & Nicaragua & Matagalpa, Selva Negra & KX998947 & & & TK 93678 & 18 \\
\hline
\end{tabular}

(MRL), and palatal breadth (PB) from specimens from $7.4 \mathrm{mi}$ WSW Dos Aguas $(n=7)$. Measurements were also taken from a specimen from Guerrero that has the same field number (GK 3388) as the specimen from which a Cytb sequence was reported of $P$. winkelmanni by Sullivan et al. (1997).

Estimation of descriptive statistics (mean, range, and standard deviation) of all measurements was calculated for specimens of $P$. winkelmanni. Measurements from the Guerrero specimen (GK 3388, TCWC 045175) were compared to the descriptive statistics obtained from this sample of $P$. winkelmanni and those provided by Carleton (1977) including those of the holotype.

\section{Results}

The initial Neighbor-Joining analysis of the Cytb dataset recovered sequence FJ214688, reported from a $P$. aztecus oaxacensis, as an outlier to both the P. aztecus and P. boylii clusters. A Nucleotide Blast of this sequence recovered 99 to $98 \%$ identities with sequences of $P$. nicaraguae and $P$. nudipes of the $P$. mexicanus species group.

The expanded Cytb dataset, including representative taxa of the $P$. mexicanus species group, was partitioned by codon position. The Bayesian analysis using a GTR+I+G model for codons 1 and 3 and a GTR+I model for codon 2, recovered a well-supported phylogenetic tree (Fig. 1). The Cytb sequence (FJ214688) reported to be from a $P$. a. oaxacensis from Honduras (TK 101037) was recovered in a wellsupported clade with sequences from taxa of the $P$. mexicanus species group sister to a sequence from a $P$. nudipes. The $\mathrm{K} 2 \mathrm{P}$ distance between this sequence and sequences from the $P$. aztecus species group ranged between 13.4 to 17.5 $\%$ (Table 2) whereas the differentiation from a $P$. nudipes 
sequence was only $1.9 \%$. The Bayesian analysis of concatenated sequences using a GTR+I+G model for Cytb codons 1 and 3, HKY+I for Cytb codon 2, and HKY+G for Adh-1-12 and Fgb-17 recovered specimen TK 101037 from Honduras in the mexicanus species group clade as the sister taxon to $P$. nudipes (Figure 2). A p-distance of $0.3 \%$ of the $\mathrm{Fgb}-\mathrm{I7}$ sequence FJ214714 was found with a $P$. nudipes sequence, but the Adh-1-12 sequence FJ214675 from this specimen had a p-distance of $5.7 \%$ from the $P$. nudipes sequence and values $>3.2 \%$ from all taxa of the $P$. aztecus group for which Adh-1-12 sequences were available.

The remaining 30 Cytb sequences reported to be from taxa of the $P$. aztecus species group were recovered in a well-supported clade $(\mathrm{ML}=87 ; \mathrm{PP}=1.00)$ that was sister to a well-supported clade $(\mathrm{ML}=99 ; \mathrm{PP}=1.00)$ of taxa of the $P$. boylii species group (Figure 1). Five subclades were recovered in the aztecus group clade representing $P$. winkelmanni, P. spicilegus, P. a. oaxacensis southeast of the Isthmus of Tehuantepec, $P$. hylocetes, and a clade contain- ing aztecus, evides, and oaxacensis from northwest of the Isthmus of Tehuantepec. Although P. winkelmanni showed the greatest divergence from other taxa of the $P$. aztecus group (mean K2P $=8.79 \%$ ), its affinities were clearly with this group and not with the boylii group.

Sequences of Cytb from the gleaning mouse, P. spicilegus, were recovered in a well-supported $(M L=99 ; P P=1.00)$ clade (Figure 1) that was divergent from other clades in the aztecus group with a mean K2P distance of $8.71 \%$ (Table 2). Two subclades were recovered in the spicilegus clade, one containing northern samples from Durango and the other more southern samples from Michoacán and Jalisco. The mean K2P differentiation between these southern and northern groups was $3.33 \%$.

Although a Fgb-17 sequence and three Adh-1-12 sequences (Table1) are available from specimens of $P$. spicilegus, only one of the $A d h$ sequences is from a specimen (TK 47888) for which a Cytb sequence is available. The analyses of the concatenated sequences from TK 47888 recover

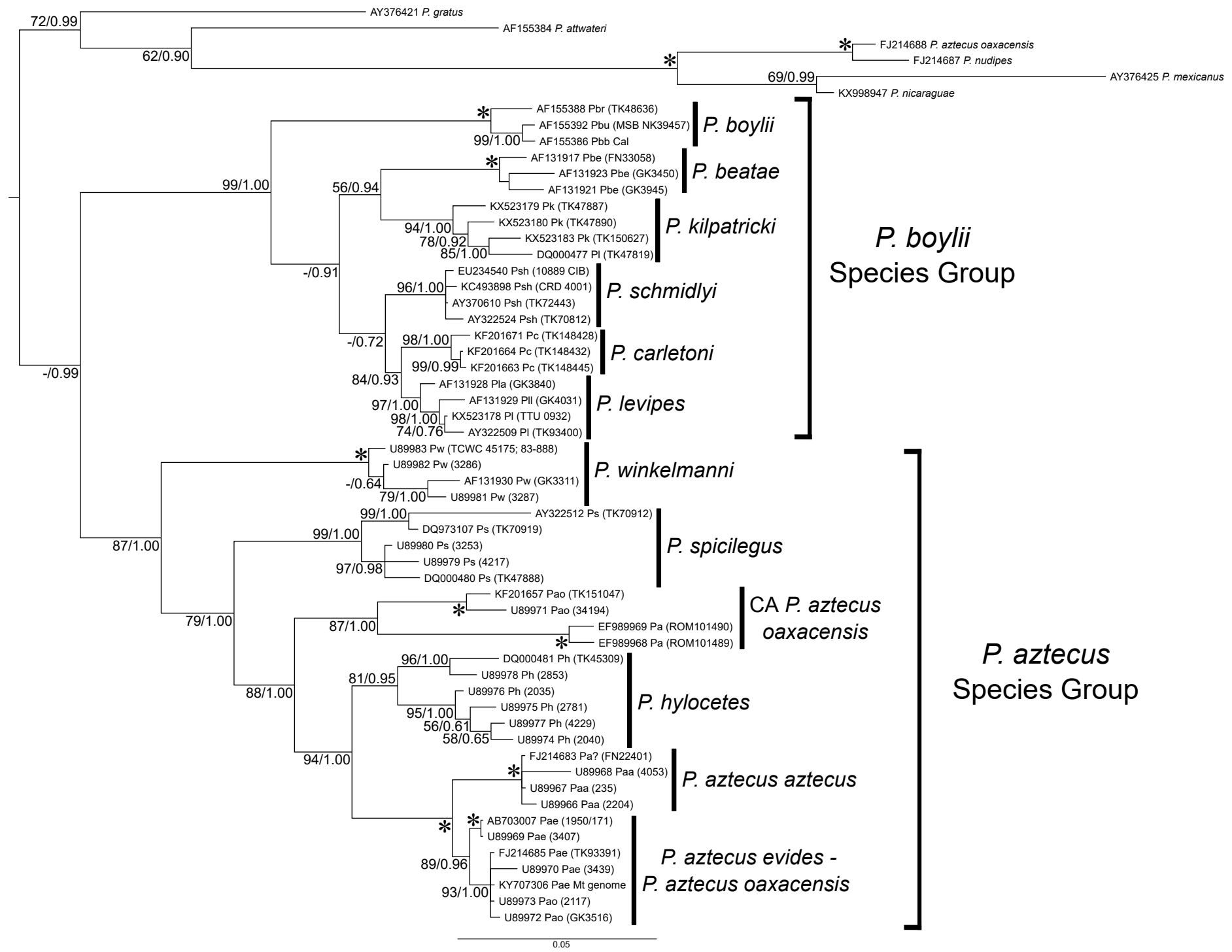

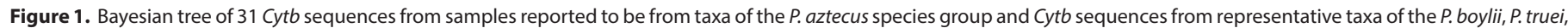

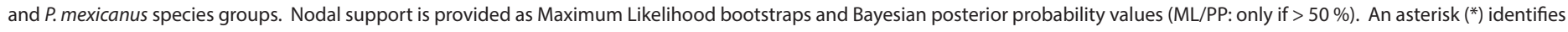
nodes with fully realized support $(M L=100$ and $P P=1.00)$. 


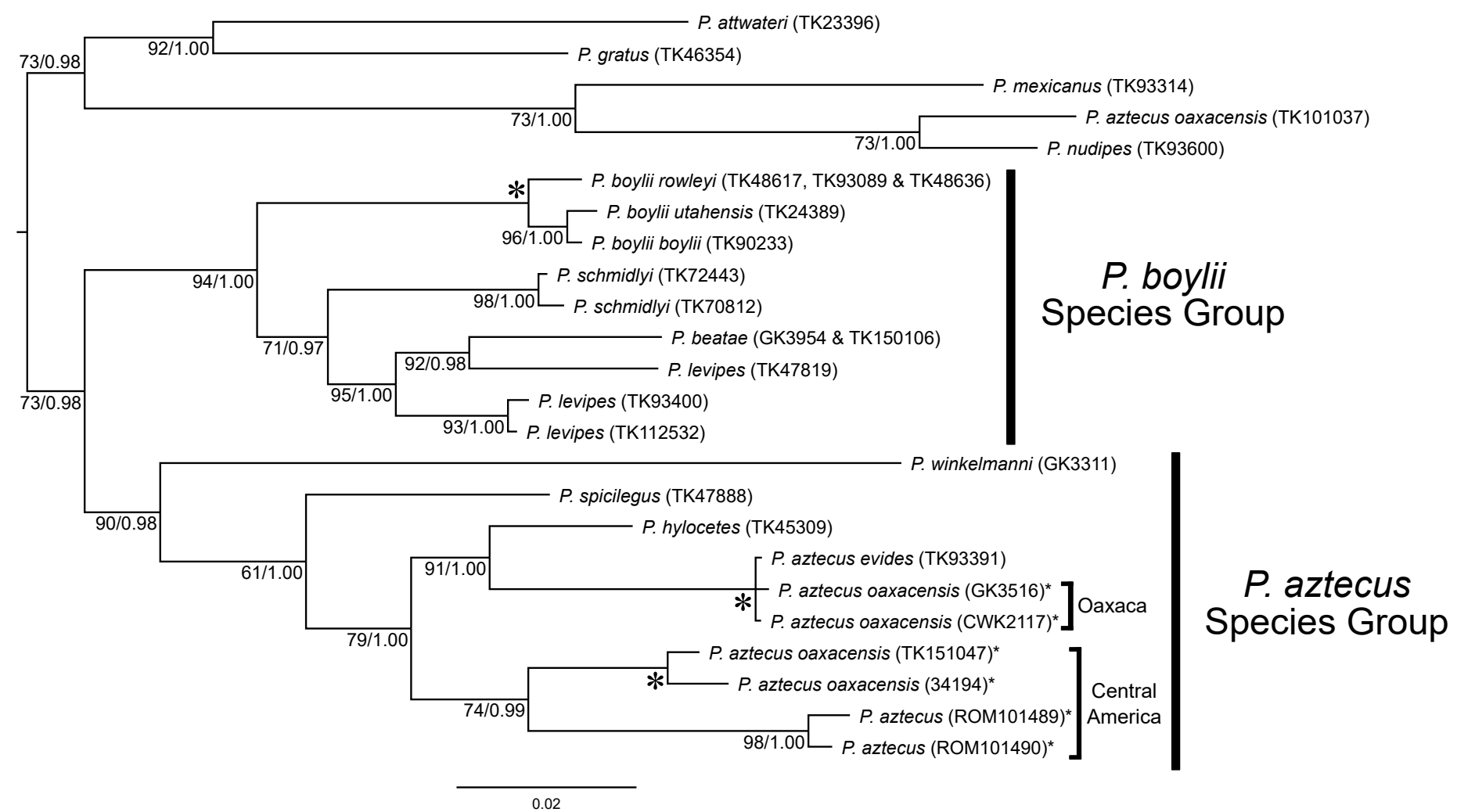

Figure 2. Bayesian tree of concatenated sequences ( $C y t b, A d h-1-12$, and $F g b-17)$ from samples reported from five taxa of the $P$. aztecus species groups and representative samples from the P. boylii, P. truei, and P. mexicanus groups. Individuals represented only by a Cytb sequence are indicated with an asterisk (*) following the sample number. Nodal support is provided as Maximum Likelihood bootstraps and Bayesian posterior probability values (ML/PP: only if $>50 \%)$. An asterisk (*) identifies nodes with fully realized support (ML $=100$ and PP $=1.00$ ).

this specimen of $P$. spicilegus as sister to a hylocetes-aztecusCentral American oaxacensis clade (Figure 2).

Populations of $P$. a. oaxacensis from Central America (southeast of the Isthmus of Tehuantepec) were recovered in a well-supported ( $\mathrm{ML}=87 ; \mathrm{PP}=1.00$ ) clade (Figure 1) containing two well-supported subclades, one with samples from Guatemala and the other samples from El Salvador. The mean genetic differentiation (K2P) between these two subclades was $7.5 \%$. Samples of $P$. a. oaxacensis from northwest and southeast of the Isthmus of Tehuantepec had a mean K2P divergence of $7.9 \%$ (Table 2). A similar topology for these samples was recovered in the analyses of the concatenated dataset (Figure 2), though only Cytb sequence data were available for samples of P. a. oaxacensis.

The remaining samples representing populations of aztecus, evides, hylocetes, and oaxacensis from north of the Isthmus of Tehuantepec were recovered in a well-supported $(\mathrm{ML}=94 ; \mathrm{PP}=1.00$ ) clade (Figure 1) sister to the oaxacensis clade from south of the Isthmus. Within the former clade, samples of hylocetes form a moderately well-supported (ML $=81 ; \mathrm{PP}=0.95$ ) clade with a mean genetic differentiation (K2P) of $5.5 \%$ from the aztecus-evides-northern oaxacensis clade (Fig. 1). Analyses of the concatenated dataset recovered hylocetes within a well-supported clade $(\mathrm{ML}=91 ; \mathrm{PP}=$ 1.00) as the sister taxon of evides and northern oaxacensis (Figure 2).

Two well-supported subclades were recovered in the P. aztecus clade from northwest of the Isthmus of Tehuan- tepec, one including samples of $P$. a. evides and northern samples of $P$. a. oaxacensis (Figure 1). Little genetic differentiation (mean K2P $=0.005$ ) was observed between samples of P. a. evides from the Sierra Madre del Sur and the P. $a$. oaxacensis from the highlands of central Oaxaca. The other subclade contained samples of $P$. a. aztecus and a sequence (FJ214683) of a P. aztecus reported to be from $5 \mathrm{~km}$ E Dos Aguas in Michoacán (Figure1), a location from which $P$. aztecus has not previously been reported.

If the sequences for $P$. a. aztecus from two specimens (FN 22401 and TK 45255) both reported from $5 \mathrm{~km}$ E Dos Aguas, Michoacán, a locality well outside of the known range of this subspecies (Carleton 1989) are included in the concatenated dataset, this concatenated sequence of $P$. aztecus is recovered as sister to a hylocetes-evides-northern oaxacensis clade. The Cytb sequence from FN 22401 (FJ214683) was recovered in the $P$. a. aztecus clade with strong support $(\mathrm{ML}=100 ; \mathrm{PP}=1.00)$ in the phylogenetic analyses of the Cytb dataset (Figure 1). The Fgb-17 sequence from TK 45255 (FJ214695) was found to have p-distances of $1.0 \%$ from $P$. spicilegus, $2.5 \%$ from $P$. nudipes, and $3.2 \%$ from $P$. hylocetes and $P$. a. evides sequences. The Adh sequence from TK 45255 (FJ214669) had a p-value $>3.2 \%$ from all comparisons with $P$. aztecus species group taxa. A concatenation of these sequences was not included in our analyses.

Body and skull measurements from the voucher from Guerrero (GK 3388, TCWC 45175) for Cytb sequence U89983 from a $P$. winkelmanni was smaller for head and body length, 


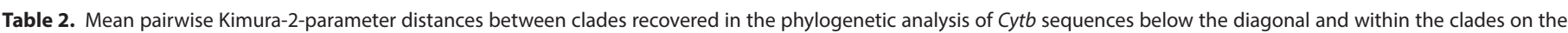
diagonal.

\begin{tabular}{|c|c|c|c|c|c|c|c|c|c|}
\hline Taxa & P. a. aztecus & P. a. evides & P.a. oaxacensis & P. hylocetes & P. spicilegus & P. winkelmanni & $\begin{array}{l}\text { P. aztecus } \\
\text { El Salvador }\end{array}$ & $\begin{array}{l}\text { P. aztecus } \\
\text { Guatemala }\end{array}$ & $\begin{array}{l}\text { P. aztecus } \\
\text { Honduras }\end{array}$ \\
\hline P. a. aztecus & 0.0076 & & & & & & & & \\
\hline P. a. evides & 0.0295 & 0.0077 & & & & & & & \\
\hline P. a. oaxacensis & 0.0302 & 0.0050 & 0.0015 & & & & & & \\
\hline P. hylocetes & 0.0642 & 0.0503 & 0.0494 & 0.0262 & & & & & \\
\hline P. spicilegus & 0.0901 & 0.0876 & 0.0826 & 0.0805 & 0.0273 & & & & \\
\hline P. winkelmanni & 0.0881 & 0.0836 & 0.0824 & 0.0836 & 0.0833 & 0.0135 & & & \\
\hline P. aztecus El Salvador & 0.0881 & 0.0912 & 0.0781 & 0.0770 & 0.1019 & 0.1049 & 0.0125 & & \\
\hline P. aztecus Guatemala & 0.0838 & 0.0708 & 0.0798 & 0.0777 & 0.0835 & 0.0892 & 0.0747 & 0.0175 & \\
\hline P. aztecus Honduras ${ }^{1}$ & 0.1597 & 0.1655 & 0.1589 & 0.1530 & 0.1534 & 0.1454 & 0.1749 & 0.1338 & NA \\
\hline
\end{tabular}

the greatest length of skull and brain-case width, and at the minimal range for hind foot and molar row length compared with measurements from $P$. winkelmanni (Table 3). This specimen is cataloged as TCWC 45175 and identified as a P.a. evides collected on 30 July 1983 from Filo de Caballos, $7,900 \mathrm{ft}$, Guerrero, México. The sequence U89983 does, however, belong to the $P$. winkelmanni clade (Figure 1).

\section{Discussion}

Sequences associated with incorrect data. Several misplaced or problematic sequences were detected while downloading sequences or in our phylogenic analyses, including sequences FJ214688 (Cytb), FJ214675 (Adh), and FJ214714 (Fgb) from specimen TK 101037 (TTU 83698) from Francisco, Morazán, La Tigra Parque Nacional in Honduras identified in GenBank as from P. a. oaxacensis (Table 4). The specimen, TTU 83698 (TK 101037) is catalogued in Vertnet as a P. mexicanus and the results of the analysis of the Cytb sequence (FJ214688) and an analysis including a concatenation of these three sequences recovered this specimen within the $P$. mexicanus species group, sister to a specimen of $P$. nudipes. Based on our molecular analyses, sequences from TK 101037 from Honduras appear to be from a P. nudipes and not a P. aztecus, however, the Adh sequence FJ214675 from this specimen demonstrates a p-distance greater than 5.0 $\%$ from $P$. nudipes, suggesting contamination or concatenation of this sequence with some other taxon (Table 4).
Other problematic sequences include the collecting locality for FJ214683 (Cytb) and the taxon from which sequences FJ214669 (Adh), FJ214695 (Fgb) and AY994234 (Adh) were obtained (Table 4). These issues were resolved by examining the identification of the voucher specimen in Vertnet and/or calculating K2P (Cytb) or the p-distance (Adh and Fgb) to sequences of reference taxa. Cytochrome $b$ sequence FJ214683 appears to be from a P. a. aztecus from Veracruz whereas AY994234 (Adh) and FJ214695 (Fgb) appear to be from a P. spicilegus from Michoacán (Table 4). Although the Adh sequence FJ214669 is reported to by from the same specimen (TK 45255) as Adh sequences AY994234, these two sequences have a p-distance of $3.9 \%$.

Once taxon source misidentifications or incorrect localities are recognized for sequences, the database (GenBank) needs to be corrected (see https://ncbi.nlm.nih.gov/genbank/update/ for instructions). Without correction of taxon misidentification and incorrectly reported source localities in the database the use of these sequences and their reported collecting localities will continue and may cause confusion in the literature. Sequence FJ214669 should be excluded from future analyses until its source can be verified.

Distribution of P. winkelmanni. Peromyscus winkelmanni was described by Carleton (1977) from a series of 12 specimens collected by John R. Winkelmann and Floyd Downs from $6.3 \mathrm{mi}$ (by road) WSW Dos Aguas, Michoacán, México at an elevation of 8,000 feet. Additional specimens of this

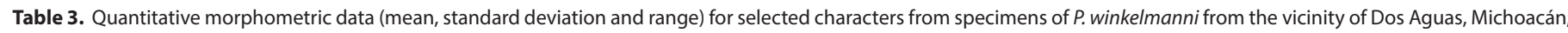
and a voucher (TCWC 045175) associated with the development of a hypothesis of a population in the vicinity of Filo de Caballo, Guerrero.

\begin{tabular}{|c|c|c|c|c|c|c|c|c|c|c|}
\hline \multirow[b]{2}{*}{ Source } & \multirow[b]{2}{*}{$\mathbf{n}$} & \multicolumn{4}{|c|}{ Body Measurements } & \multicolumn{5}{|c|}{ Skull Measurements } \\
\hline & & TL & HB & LT & HF & GLS & $\mathrm{BCW}$ & ZB & IOW & MRL \\
\hline Holotype & & 263 & 123 & 140 & 29 & 33.3 & 14.3 & ---- & 5.3 & 5.2 \\
\hline Carleton (1977) & 32 & $249.2 \pm 11.2$ & ---- & $129.1 \pm 7.9$ & $27.6 \pm 0.67$ & $32.5 \pm 0.88$ & ---- & $16.2 \pm 0.56$ & ---- & $5.3 \pm 0.14$ \\
\hline Range & & $235-265$ & ---- & $120-140$ & $27-29$ & $31.2-33.9$ & ---- & $15.4-17.1$ & ---- & $5.1-5.6$ \\
\hline Michoacán & 16,7 & $254.9 \pm 13.3$ & $122.9 \pm 4.66$ & $132 \pm 10.4$ & $27.4 \pm 0.96$ & $32.4 \pm 0.88$ & $14.1 \pm 0.32$ & $16.0 \pm 0.70$ & $5.5 \pm 0.16$ & $5.3 \pm 0.24$ \\
\hline Range & & $230-273$ & $113-133$ & 117-149 & $26-28$ & $30.7-33.6$ & 13.4-14.3 & $14.8-16.8$ & $5.3-5.7$ & $5.1-5.5$ \\
\hline Guerrero & 1 & $190+$ & 112 & $78+$ & 26 & 29.8 & 13.3 & 15.5 & 5.4 & 5.1 \\
\hline
\end{tabular}


taxon from the vicinity of Dos Aguas have been reported by Carleton (1977), Álvarez et al. (1987) and this study (Appendix 1). Although Carleton (1977) speculated that this taxon inhabited other areas of the coastal sierra in Michoacán, no additional populations have been discovered in Michoacán.

Smith et al. (1989) reported a specimen of $P$. winkelmanni based on the detection of a karyotype with a $\mathrm{FN}=70$ and only three large pairs of biarmed chromosomes from the vicinity of Filo de Caballos in Guerrero. Based on this karyotype, which was identical to karyotypes of $P$. winkelmanni from Dos Aguas, Smith et al. (1989) concluded that the geographic range of $P$. winkelmanni extended at least from southwestern Michoacán through the Sierra Madre del Sur in Guerrero. Although no voucher number was provided by Smith et al. (1989) for the Guerrero specimen, the field catalog (examined by CWK) records only one specimen (GK 3388) collected from "Guerrero, Filo de Caballo vicinity". This male specimen was initially identified as a "P. evides" and later noted to have a FN $=70$ with comments later written in the margin including "P. evides? or in P. mexicanus group" and "P. winkelmanni".

Sullivan and Kilpatrick (1991) reported on the allozymes of $P$. winkelmanni from three locations WSW of Dos Aguas and two specimens from $4 \mathrm{mi} S$ Filo de Caballos. Phenetic and cladistic analyses of these biochemical data supported the contention of Smith et al. (1989) as they placed these samples from Filo de Caballo in a P. winkelmanni cluster or clade. However, vouchers were not identified for the sources of tissues used by Sullivan and Kilpatrick (1991).

The molecular analysis of the $P$. aztecus species group by Sullivan et al. (1997) identifies the vouchers associated with the $P$. winkelmanni sequences in the appendix (page 439). Three sequences were obtained from two specimens (3286 and 3287) from $19.3 \mathrm{~km}$ WSW Dos Aguas, Michoacán, and a specimen (3388) from Filo de Caballo, Guerrero.

The specimen with the field number GK 3388 was cataloged as TCWC 045175 and is smaller in several measurements than a series of $P$. winkelmanni, including GK 3286 (TCWC 045614) and GK 3287 (TCWC 045615). The voucher for GK 3388 is cataloged as a $P$. aztecus evides and is not a $P$. winkelmanni based on our comparison of measurements. Thus, there are no vouchers available for specimens of $P$. winkelmanni from Guerrero. We suspect that the sequence obtained by Sullivan et al. (1997) was likely obtained from specimen GK 3288, a P. winkelmanni from $19.3 \mathrm{~km}$ WSW of Dos Aguas and cataloged as TCWC 045616. Mislabeling of Nunc tubes, slides, and other material associated with specimen GK 3288 led to reports of $P$. winkelmanni occurring in Guerrero. Given the absence of a voucher of a specimen of $P$. winkelmanni from Guerrero, the distribution of the forest mouse should be restricted to the vicinity of Dos Aguas, Michoacán.

Taxonomy of the P. aztecus species group. With the utilization of molecular data and the expansion of species concepts, the content of the genus Peromyscus has been expanded from 53 species recognized by Carleton (1989) and Musser and Carleton (1993), to 56 species recognized by Musser and Carleton (2005), to 66 species recognized by Pardiñas et al. (2017) and to 78 species currently recognized in the Mammal Diversity Database (Mammal Diversity Database 2020). Over 20 new species of Peromyscus have been recognized just in the past 10 years (Ávila-Valle et al. 2012; Bradley et al. 2014, 2015, 2017, 2019; Pérez-Consuegra and Vazquez-Domínguez 2015; Greenbaum et al. 2019; Lorenzo et al. 2016; Álvarez-Castañeda et al. 2019; López-González et al. 2019; Léon-Tapia et al. 2020).

Molecular data have been used to examine the phylogeography and phylogenetic relationships of several species groups including the P. aztecus (Sullivan et al. 1997), $P$ boylii (Bradley et al. 2000; Tiemann-Boege et al. 2000), $P$. maniculatus (Bradley et al. 2019; Greenbaum et al. 2019), P. mexicanus (Pérez Consuegra and Vázquez-Domínguez 2015; Bradley et al. 2016) and P. truei (Durish et al. 2004) species groups. The molecular study of the P. aztecus species group by Sullivan et al. (1997) was conducted, however, before the development of several modern molecular phylogenetic approaches and their associated software and was based on short ( $<750 \mathrm{bp}$ ) fragments of the Cytb gene.

The content of the $P$. aztecus species group has increased from three species, P. winkelmanni, P. spicilegus, and $P$. aztecus proposed by Carleton $(1979,1989)$, to four with the reinstatement of $P$. hylocetes as a distinct species (Sullivan and Kilpatrick 1991; Sullivan et al. 1997; Musser and Carleton 2005), to five species with the reinstatement of P. oaxacensis as a distinct species (Duplechin and Bradley 2014; Bradley 2017). Although our molecular analyses are congruent with the recognition of five distinct species in the $P$. aztecus species group, we do not support recognition of $P$. oaxacensis as a distinct species.

Peromyscus oaxacensis was described as a distinct species by Merriam (1898) based on specimens from Cerro San Felipe, Oaxaca, México, 10,000 ft. This taxon was recognized as a species (Osgood 1909; Hall and Kelson 1959; Hooper and Musser 1964; Hooper 1968; Goodwin 1969; Hall 1981) with a distribution in the highlands of Oaxaca and Chiapas, México. Musser (1969) pointed out that the range of $P$. oaxacensis extended southward into Guatemala, El Salvador, and western Honduras. Hooper (1968) questioned whether $P$. oaxacensis and $P$. hylocetes might represent disjunct populations of a single species. Carleton (1977) concurred with Hooper's (1968) hypothesis and later formally placed oaxacensis and hylocetes together with evides as subspecies of P. aztecus (Carleton 1979).

The Isthmus of Tehuantepec has been hypothesized to be an effective barrier to gene flow acting as a vicariant event contributing to the isolation, diversification, and speciation of rodent populations. Isolation by the Isthmus resulting in speciation has been reported for Habromys (León-Paniaqua et al. 2007), Microtus (Conroy et al. 2001), and Neotoma (Ordóñez-Garza et al. 2014). Ordóñez-Garza and Bradley (2018) examined DNA sequence variation 
within populations of 11 species of cricetid rodents distributed across the Isthmus of Tehuantepec and found that the Isthmus only appeared to be an effective barrier to gene flow in the montane species Reithrodontomys sumichrasti. Sullivan et al. (2000) compared the phylogeography of this highland forest dwelling harvest mouse, $R$. sumichrasti, to the previously published (Sullivan et al. 1997) phylogeography of the co-distributed $P$. aztecus/P. hylocetes complex and concluded that these two species share a more common biogeographic history than can be accounted for by the independent response hypothesis.

Our analyses support the conclusion of Sullivan et al. (1997) that forms of $P$. a. oaxacensis southeast of the Isthmus of Tehuantepec represents a distinct species. Specimens from northwest of the Isthmus, including samples from near the type locality of $P$. oaxacensis in the highlands of Oaxaca, show little genetic differentiation from $P$. a. evides in the Sierra Madre del Sur. Our analyses do not support the inclusion of populations of oaxacensis from the Oaxacan highlands as a distinct species from $P$. aztecus as suggested by Bradley et al. (2017). Duplechin and Bradley (2014) questioned the taxonomic affinities of these Oaxacan highland populations, but we conclude they should be recognized as conspecific with $P$. aztecus
(Figure 3) following Carleton (1979).

Samples of oaxacensis from southeast of the Isthmus form a well-supported clade, sister to a P. hylocetes- $P$. aztecus clade (Figures 1 and 2) but demonstrate considerable genetic differentiation from taxa of that sister clade. Two names appear to be available for this taxon. Peromyscus hondurensis Goodwin, 1941, was described from specimens from western Honduras (Muya, $5 \mathrm{mi}$ N Chinacla, department La Paz, Honduras, 3,000 to 4,000 ft.), but was considered a southern representative of $P$. oaxacensis by Musser (1969). This taxon is represented in our sampling by two specimens from Guatemala (TK 151047 and 34194). Another potentially available name for this taxon is cordillerae described from specimens from northeastern El Salvador (Mt. Cacahuatique, Dept. San Miguel, 3,500 feet) as a subspecies of P. boylii by Dickey (1928) but considered a subspecies of $P$. aztecus by Carleton (1979). The samples from Parque Nacional Montecristo, El Salvador (ROM 101489 and ROM 101490), may or may not correspond to this taxon. Regardless, the available data advocate for the recognition of all populations of the $P$. aztecus species group located south of the Isthmus of Tehuantepec as a distinct species, and Peromyscus cordillerae Dickey, 1928, has priority (International Commission on Zoological Nomenclature 1999).

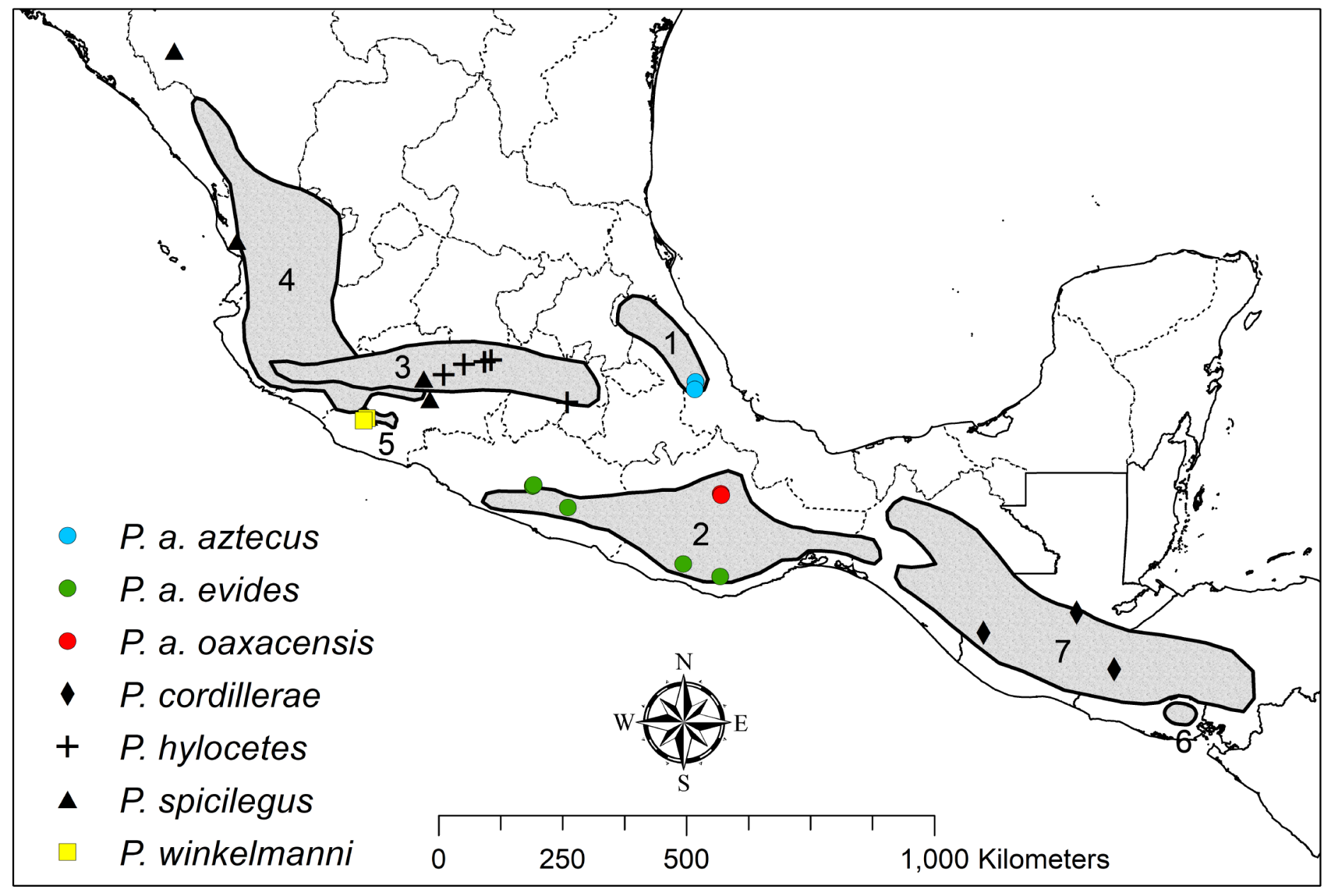

Figure 3. Distribution of taxa of the P. aztecus species group (map modified from Carleton 1989): 1) P. aztecus aztecus. 2) P. a. evides - P. a. oaxacensis. 3) P. hylocetes. 4) P. spicilegus. 5) P. winkelmanni. 6) P. cordillerae cordillerae, and 7) P. cordillerae hondurensis. 
We suggest that $P$. cordillerae occurs in Guatemala, El Salvador, western Honduras, and the southern highlands of Chiapas, México (Figure 3). Further field and laboratory work are needed to resolve the geographic separation of $P$. a. oaxacensis and P. cordillerae in Chiapas. Two well-supported and highly differentiated subclades were recovered in the $P$. cordillerae clade, thus more than a single species may be present. Despite the high level of differentiation observed we refrain from further expansion of the number of Central American taxa of the P. aztecus group until samples are available from near the type localities on Mt. Cacahuatique (cordillerae) and in western Honduras (hondurensis). Instead, we tentatively consider cordillerae and hondurensis as distinct at only a subspecies level.

Levels of divergence and cladistic analyses of sequence data in this study support the earlier conclusion that $P$. hylocetes should be recognized as a distinct species (Sullivan and Kilpatrick 1991; Sullivan et al. 1997). Although morphological similarities are present between hylocetes and P. a. oaxacensis, Carleton (1979) pointed out that these morphological features appear to be subject to ele- vational effects and these two taxa both occur at higher elevations. In addition to biochemical and genetic divergence, Smith et al. (1989) reported differences in karyotypes with $P$. hylocetes having a $\mathrm{FN}=72-74$ and $P$. aztecus a $\mathrm{FN}=68-70$.

The data concerning the relationships of the allopatric subspecies of $P$. aztecus are difficult to interpret due to the inclusion of hylocetes as a subspecies but are generally incongruent (Bradley et al. 1990). However, phenetic analysis of both quantitative data for the glans and bacula (Bradley et al. 1990) and allozymic data (Sullivan and Kilpatrick 1991) identified P. a. aztecus as being distinct from the other subspecies. Phylogenetic analyses (Sullivan et al. 1997; this study) of sequence data recovered P. a. evides and $P$. a. oaxacensis in the same clade. In this study, less mean divergence was observed between $C y t b$ sequences of $P$. a. evides and sequences of $P$. a. oaxacensis (K2P $=$ $0.5 \%$ ) than among sequences of $P$. evides (K2P $=0.77 \%$ ). This lack of differentiation between these populations in the highlands of central Oaxaca and the Sierra Madre del Sur questions whether these two subspecies are allopat-

Table 4. Determination of collecting locality and likely source taxon for problematic GenBank data. Most likely source taxon is designated with an asterisk in the remarks.

\begin{tabular}{|c|c|c|c|c|c|c|c|}
\hline $\begin{array}{c}\text { Sequence } \\
\text { Accession } \\
\text { Number }\end{array}$ & $\begin{array}{l}\text { Gene or } \\
\text { Intron }\end{array}$ & GenBank ID & $\begin{array}{l}\text { Specimen Catalog } \\
\text { Number }\end{array}$ & Collecting Locality & Vertnet ID & $\begin{array}{l}\text { Bayesian Analyses A) } \\
\text { Cytb; B) concatenated }\end{array}$ & Remarks \\
\hline FJ214688 & Cytb & P. a. oaxacensis & TK 101037 TTU 83698 & $\begin{array}{l}\text { Francisco, Morazán La Tigra Parque Nacio- } \\
\text { nal, Honduras }\end{array}$ & P. mexicanus & A: Sister to P. nudipes & $\begin{array}{l}\text { K2P distance of } \\
1.9 \% \text { from } P . \text { nudi- } \\
\text { pes }^{1} ;>13 \% \text { from } \\
\text { taxa of } P . \text { aztecus } \\
\text { group } \\
\text { P. nudipes* }\end{array}$ \\
\hline FJ214675 & Adh-12 & P. a. oaxacensis & TK 101037 TTU 83698 & $\begin{array}{l}\text { Francisco, Morazán La Tigra Parque Nacio- } \\
\text { nal, Honduras }\end{array}$ & P. mexicanus & B: Sister to P. nudipes & $\begin{array}{l}\text { p-distance of } 5.7 \\
\% \text { from P. nudipes } \\
\text { contamination or } \\
\text { concatenation with } \\
\text { sequence of some } \\
\text { other taxon }\end{array}$ \\
\hline FJ214714 & $\mathrm{Fgb}-17$ & P. a. oaxacensis & TK 101037 TTU 83698 & $\begin{array}{l}\text { Francisco, Morazán La Tigra Parque Nacio- } \\
\text { nal, Honduras }\end{array}$ & P. mexicanus & B: Sister to $P$. nudipes & $\begin{array}{l}\text { p-distance of } 0.3 \% \\
\text { from P. nudipes }{ }^{3} \\
\text { P. nudipes* }\end{array}$ \\
\hline FJ214683 & Cytb & P. aztecus & FN 2401 ROM 100795 & 5 km E Dos Aguas, Michoacán, México & P. aztecus & A. within P. a. aztecus clade & $\begin{array}{l}\text { Vertnet locality } \\
\text { given as Veracruz. } \\
\text { P. a. aztecus* }\end{array}$ \\
\hline FJ214669 & Adh-12 & P. aztecus & TK 45255 & 5 km E Dos Aguas, Michoacán, México & Not found & & $\begin{array}{l}\text { p-distance of } 6.0 \\
\% \text { from } P \text {. a. evides } \\
\text { and } 3.2 \% \text { from } P \text {. } \\
\text { spicilegus } 5 \\
\text { Unknown taxon* }\end{array}$ \\
\hline FJ214695 & $F g b-17$ & P. aztecus & TK 45255 & 5 km E Dos Aguas, Michoacán, México & Not found & & $\begin{array}{l}\text { p-distance of } 5.1 \\
\% \text { from P. a. evides } \\
\text { and } 1.2 \% \text { from } P \text {. } \\
\text { spicilegus }^{7} \\
\text { P. spicilegus* }\end{array}$ \\
\hline AY994234 & Adh-12 & P. spicilegus & TK 45255 & 5 km E Dos Aguas, Michoacán, México & Not found & & $\begin{array}{l}\text { p-distance of } 0.3 \% \\
\text { from P. spicilegus }{ }^{5} \\
\text { P. spicilegus* }\end{array}$ \\
\hline
\end{tabular}

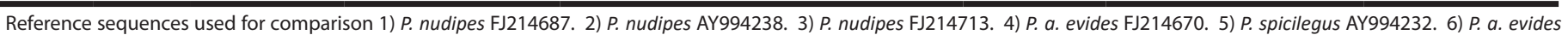
FJ214700. 7) P. spicilegus FJ214719 
ric. More thorough sampling in the rugged mountains of Oaxaca is needed to understand the level of differentiation and distribution of these two subspecies. Unlike species, however, subspecies need not exhibit reciprocal monophyly (Patton and Conroy 2017).

Considerable local and individual variation was observed among samples of $P$. a. evides from Oaxaca (Goodwin 1969). In general P. a. evides is smaller in size, has less inflated bullae, sparsely haired tails, and exhibits subtle differences in pelage coloration when compared to $P$. a. oaxacensis (Carleton, 1989). Whether such differences are diagnostic and geographically discrete enough to warrant subspecies status remains to be seen. Goodwin (1969, map 67) found samples of these two taxa to overlap broadly. However, these reported morphological differences might function on a gradient (see Carleton 1979) from the lower elevation (evides) to the higher elevation (oaxacensis). Both a morphological and molecular evaluation of these taxa in the context of broader geographic sampling that includes type material is required. Until subject to more detailed study, we do not yet recommend that evides be synonymized with P. a. oaxacensis.

Considerable morphological (Bradley et al. 1996) and chromosomal variation (Carleton et al. 1982; Smith et al. 1989; Smith 1990) has been reported among populations of $P$. spicilegus but no apparent congruence was found (Bradley et al. 1996). A possible association of the morphological data with the allozymic data of Sullivan and Kilpatrick (1991) was discussed by Bradley et al. (1996). The fixed allelic difference reported by Sullivan and Kilpatrick (1991) between samples of $P$. spicilegus from Michoacán and Nayarit, occurred in populations that were quite distinct morphologically (Bradley et al. 1996). Although sequence data are not available for specimens of $P$. spicilegus from Nayarit, data are available from southern Durango. Considerable differentiation $(\mathrm{K} 2 \mathrm{P}=0.033)$ was detected between northern (Durango) and southern samples (Jalisco and Michoacán) in this study, like what was found in the morphometric study (Bradley et al. 1996). In addition, morphological divergence was reported along an elevational gradient in Jalisco, with individuals at higher elevations being larger (Sánchez-Cordero and Villa-Ramírez 1988). Further examination of molecular and morphological data is needed before subspecific recognition can be proposed.

Although additional research is needed to clarify the correct taxonomic position of several forms, we believe the following represents a concise summary of the most appropriate taxonomic designations in the Peromyscus aztecus species group based on available data. Nine taxa have been named in this species group and we here recognize five of these at the rank of species, three as additional subspecies, and one as a junior synonym (Figure 3). Peromyscus winkelmanni Carleton, 1977, is found in the vicinity of Dos Aguas, Michoacán, and is sister to all other members of the species group. Peromyscus spicilegus J. A. Allen, 1897, is found on the flanks of the Sierra Madre Occidental. Peromyscus cordillerae represents all members of the species group southeast of the Isthmus of Tehuantepec and is comprised of two subspecies, P. c. cordillerae Dickey, 1928, and P. c. hondurensis Goodwin, 1941, the boundaries of which remain poorly understood. Peromyscus hylocetes Merriam, 1898, is found at mid to high elevations in the Transmexican Volcanic Belt. The range of $P$. aztecus appears to be restricted to northwest of the Isthmus of Tehuantepec and the species contains three subspecies. Peromyscus a. aztecus (Saussure, 1860 ) is found in the Sierra Madre Oriental. The geographic delineation of the remaining two subspecies, P. a. oaxacensis Merriam, 1898, and P. a. evides Osgood, 1904 (including yautepecus Goodwin, 1955), remains poorly defined. Future research on the $P$. aztecus species group should focus on clarifying the status of $P$. $a$. oaxacensis versus $P$. a. evides and on P. c. hondurensis versus P. c. cordillerae. Such studies should also investigate the potential for unrecognized species or subspecies diversity in P. cordillerae, P. spicilegus, and $P$. hylocetes.

\section{Acknowledgments}

We acknowledge M. W. Allard, D. J. Boles, R. D. Bradley, A. Castro-Campillo, G. Ceballos, K. M. Davis, J. Ensink, T. W. Houseal, J. W. Kilpatrick, S. M. Kilpatrick, L. Léon Paniagua, J. C. Morales, D. Navarro, P. E. Nuñez, P. D. Rennert, F. Romero, D. J. Schmidly, S. A. Smith, J. M. Sullivan, D. Werbitsky for the collection of many of the specimens that produce much of the data used in this study. Field work to collect that material was funded by National Science Foundation Grants: DEB 81-17447 to I. F. Greenbaum and D. J. Schmidly and DEB 81-18966 to CWK. Contributors of sequence data are identified in Table 1 where possible. We are indebted to Jessica Light for a loan of specimens from the Texas Cooperative Wildlife Collection, Texas A\&M University.

This paper is dedicated to my friend and colleague David J. Schmidly. My (CWK) collaborations with Dave stem from when we were both graduate students in the early seventies and both examining the relationships among populations of the Peromyscus boylii species group. Our collaborations on this complex group of rodents led to a series of collecting trips in México between 1982 and 1985 supported by NSF. While those collecting trips provided specimens and other materials that have contributed to numerous publications, their greatest contributions were in the training of future mammalogists. On each of those trips, Dave invited students from Universities in México to join us in conducting this field work and many of those students have gone on to become very prominent mammalogists. Dave, we are indebted to you not only for your scholarly contributions, but also for the academic offspring that that you have fostered and nurtured that continue to contribute greatly to our knowledge of mammals of the southwestern United States, México, and Central America. Congratulation on having this issue of Therya published in your honor with contributions from your students, colleagues and friends. 


\section{Literature Cited}

Allen, J. A. 1897. Further notes on mammals collected in Mexico by Dr. Audley C. Buller, with descriptions of new species. Bulletin of the American Museum of Natural History 9:47-58.

Álvarez, T., J. Arroyo-Cabrales, and M. González Escamilla. 1987. Mamíferos (excepto Chiroptera) de la costa de Michoacán, México. Anales de la Escuela Nacional Ciencias Biológicas 31:13-62.

Álvarez-Castañeda, S. T., C. Lorenzo, C. A. Segura-Trujillo, and S. G. Pérez-Consuegra. 2019. Two new species of Peromyscus from Chiapas, Mexico, and Guatemala. Pp. 543-558, in From Field to Laboratory: A Memorial volume in Honor of Robert J. Baker (Bradley, R. D., H. H. Genoways, D. J. Schmidly, and L. C. Bradley, eds.). Special Publications, Museum of Texas Tech University. Lubbock, U.S.A.

Amman, B. R. 2005. Molecular systematics of Peromyscus and allies based on nuclear and mitochondrial DNA sequences. Ph.D. dissertation, Texas Tech University. Lubbock, USA.

Amman, B. R., J. D. Hanson, L. K. Longhofer, S. R Hoofer, and R. D. BRADLEY. 2006. Intron 2 of the alcohol dehydrogenase gene (Adh-12): A nuclear DNA marker for mammalian systematics. Occasional Paper, Museum of Texas Tech University 256:1-16.

Ávila-Valle, Z. A., A. Castro-Campillo, L. León-Paniagua, I. H. Salgado-Ugalde, A. G. Navarro-Sigüenza, B. E. Hernández-BaÑOS, AND J. RAmírez-Pulido. 2012. Geographic variation and molecular evidence of the blackish deer mouse complex (Peromyscus furvus, Rodentia: Muridae). Mammalian Biology 77:166-177.

Bradley, R. D., and R. J. Baker. 2001. A test of the genetic species concept; cytochrome-b sequences and mammals. Journal of Mammalogy 82:910-973.

Bradley, R. D., AND D. J. Schmidiy. 1987. The glans penes and bacula in Latin American taxa of the Peromyscus boylii group. Journal of Mammalogy 68:595-616.

Bradley, R. D., D. S. Carroll, M. L. Haynie, R. M. Martínez, M. J. Hamilton, and C. W. Kilpatrick. 2004. A new species of Peromyscus from western Mexico. Journal of Mammalogy 85:1184-1193.

Bradley, R. D., N. D. Durish, D. S. Rogers, J. R. Miller, M. D. EngSTROM, AND C. W. KILPATRICK. 2007. Toward a molecular phylogeny for Peromyscus: evidence from mitochondrial cytochrome- $b$ sequences. Journal of Mammalogy 88:1146-1159.

Bradley, R. D., J. Q. Francis, R. N. Platt II, T. J. Soniat, D. AlVAREZ, AND L. L. LINDSEY. 2019. Mitochondrial DNA sequence data indicate evidence for multiple species within Peromyscus maniculatus. Special Publications, Museum of Texas Tech University 70:1-59.

Bradley, R. D, M. Nuñez-Tabares, T. J. Soniat, S. KerR, R. W. RayMond, AND N. Ordóñez-Garza. 2016. Molecular systematics and phylogeography of Peromyscus nudipes (Cricetidae: $\mathrm{Ne}-$ otominae). Pp. 201-214, in Contributions in Natural History: A Memorial Volume in Honor of Clyde Jones (Manning, R. M., J. R. Goetze, and F. D. Yancey, II, eds.). Special Publications, Museum of Texas Tech University 65:1-273.

Bradley, R. D., N. Ordóñez-Garza, and L. C. Bradley. 2017. Oaxacan deermouse Peromyscus oaxacensis. Pp. 392, in Handbook of the Mammals of the World, Volume 7, Rodents II (Wilson, D. E., T. E. Lacher, Jr., and R. A. Mittermeier, eds.). Lynx Edicions. Barcelona, Spain.
Bradley, R. D., N. Ordóñez-Garza, C. G. Sotero-Caio, H. M. Huynh, C. W. Kilpatrick, L. I. Iñiguez-Dávalos, and D. J. Schmidly. 2014. Morphometric, karyotypic, and molecular evidence for a new species of Peromyscus (Cricetidae: Neotominae) from Nayarit, Mexico. Journal of Mammalogy 95:176-186.

Bradley, R. D., N. Ordóñez-Garza, G. Ceballos, D. S. Rogers, and D. J. Schmidly. 2017. A new species in the Peromyscus boylii species group (Cricetidae: Neotominae) from Michoacán, México. Journal of Mammalogy 98:154-165.

Bradley, R. D., R. D. Owen, and D. J. Schmidly. 1996. Morphological variation in Peromyscus spicilegus. Occasional Papers, The Museum, Texas Tech University 161:1-23.

Bradley, R. D., D. J. SChmidly, AND R. D. Owen. 1989. Variation in the glans penes and bacula among Latin American populations of the Peromyscus boylii species complex. Journal of Mammalogy 70:712-725.

Bradley, R. D., D. J. SChmidly, and R. D. Owen. 1990. Variation in the glans penes and bacula among Latin American populations of Peromyscus aztecus. Occasional Papers, The Museum, Texas Tech University 135:1-15.

Bradley, R. D., D. J. Schmidly, B. R. Amman, R. N. Platt, II, K. M. Neumann, H. M. Huynh, R. Muñiz-Martínez, C. López-González, and N. Ordóñzz-Garza. 2015. Molecular and morphological data reveals multiple species in Peromyscus pectoralis. Journal of Mammalogy 96:446-459.

Bradley, R. D., I. Tiemann-Boege, C. W. Kilpatrick, and D. J. SchmidLy. 2000. Taxonomic status of Peromyscus boylii sacarensis inferred from DNA sequences of the mitochondrial cytochrome- $b$ gene. Journal of Mammalogy 81:875-884.

Cabrera, H., S. T. Álvarez-Castañeda, N. González-Ruiz, and J. P. Gallo-Reynoso. 2007. Distribution and natural history of Schmidly's deermouse (Peromyscus schmidlyi). Southwestern Naturalist 52:620-623.

Carleton, M. D. 1977. Interrelationships of populations of the Peromyscus boylii species group (Rodentia: Muridae) in western Mexico. Occasional Papers of the Museum of Zoology, University of Michigan 675:1-47.

Carleton, M. D. 1979. Taxonomic status and relationships of Peromyscus boylii from El Salvador. Journal of Mammalogy 60:280-296.

Carleton, M. D. 1989. Systematics and evolution. Pp. 7-141, in Advances in the study of Peromyscus (Rodentia) (Kirkland, G. L., and J. N. Layne, eds.). Texas Tech University Press. Lubbock, U.S.A.

Carleton, M. D., D. E. Wilson, A. L. Gardner, and M. A. Bogan. 1982. Distribution and systematics of Peromyscus (Mammalia: Rodentia) from Nayarit, Mexico. Smithsonian Contributions in Zoology 352:1-46.

Conroy, V. C. J., Y. Hortelano, F. A. Cervantes, and J. A. Cook. 2001. The phylogenetic position of southern relictual species of Microtus (Muridae: Rodentia) in North America. Mammalian Biology 66:332-344.

Dickey, D. R. 1928. Five new mammals of the genus Peromyscus from El Salvador. Proceedings of the Biological Society of Washington 41:1-6.

Duplechin, R. M., AND R. D. Bradley. 2014. Peromyscus oaxacensis Merrian, 1898 Oaxacan deermouse. Pp. 383-384, in Mammals of México (Ceballos, G., ed.). John Hopkins University Press. Baltimore, U.S.A. 
Durish, N. D., K. E. Halcomb, C. W. Kilpatrick, and R. D. Bradley. 2004. Molecular systematics of the Peromyscus truei species group. Journal of Mammalogy 85:1160-1169.

Goodwin, G. G. 1941. A new Peromyscus from western Honduras. American Museum Novitates 1121: 1.

Goodwin, G. G. 1955. Two new white-footed mice from Oaxaca, Mexico. American Museum Novitates 1732:1-5.

Goodwin, G. G. 1969. Mammals of the state of Oaxaca, Mexico, in the American Museum of Natural History. Bulletin of the American Museum of Natural History 141:165-362.

Greenbaum, I. F., R. L. Honeycutt, and S. E. Chirhart. 2019. Taxonomy and phylogenetics of the Peromyscus maniculatus species group. Pp 559-575, in From the Field to the Laboratory: A Memorial Volume in Honor of Robert J. Baker (Bradley, R. D., H. H. Genoways, D. J. Schmidly, and L. C. Bradley, eds.). Special Publication, Museum of Texas Tech University 71:1-911.

Guindon, S., J. F. Dufayard, V. Lefort, M. Anisimova, W. Horduk, AND O. Gascuel. 2010. New algorithms and methods to estimate maximum likelihood phylogenies: assessing the performance of PhyML 3.0. Systematic Biology 59:307-321.

Hall, E. R. 1981. The Mammals of North America. Second ed. John Wiley and Sons. New York, U.S.A.

Hall, E. R., and K. R. Kelson. 1959. The Mammals of North America. First ed. Ronald Press. New York, U.S.A.

Hooper, E. T. 1968. Classification. Pp. 27-69, in Biology of Peromyscus (Rodentia) (King, J. A., ed). Special Publication No. 2, American Society of Mammalogists. Lawrence, U.S.A.

Hooper, E. T., AND G. G. Musser. 1964. Notes on the classification of the rodent genus Peromyscus. Occasional Papers of the Museum of Zoology, University of Michigan 635:1-13.

International Commission on Zoological Nomenclature. 1999. International code of zoological nomenclature, fourth edition. The International Trust for Zoological Nomenclature, London, England.

Kımura, M. 1980. A simple method for estimating evolutionary rates of base substitutions through comparative studies of nucleotide sequences. Journal of Molecular Evolution 16:111-120.

Kumar, S., G. Stecher, And K. Tamura. 2016. MEGA7: molecular evolutionary genetic analysis version 7.0 for bigger datasets. Molecular Biology and Evolution 33:1870-1874.

Lanfear, R., B. Calcott, S. Y. Ho, and S. Guindon. 2012. PartitionFinder: combined selection of partitioning schemes and substitution models for phylogenetic analyses. Molecular Biology and Evolution 29:1695-1701.

Lanfear, R., P. B. Frandsen, A. M. Wright, T. Senfeld, and B. Calсотт. 2016. PartitionFinder 2: a new method for selecting partitioned models of evolution for molecular and morphological phylogenetic analyses. Molecular Biology and Evolution 34:772-773.

León-Paniagua, L., A. G. Navarro-Sigüenza, B. E. Hernández-BaÑOS, AND J. C. Morales. 2007. Diversification of the arboreal mice of the genus Habromys (Rodentia: Cricetidae: Neotominae) in the Mesoamerican highlands. Molecular Phylogenetics and Evolution 42:653-664.

Léon-Tapia, M. A., J. A. Fernández, Y. Rico, F. A. Cervantes, And A. Espinosa de los Monteros. 2020. A new mouse of the Peromyscus maniculatus species complex from the highlands of Central Mexico. Journal of Mammalogy 101:1117-1132.
López-González, C., M. M. Correa-Ramírez., and D. F. GarcíaMendoza. 2014. Phylogeography of Peromyscus schmidlyi: an endemic of the Sierra Madre Occidental, Mexico. Journal of Mammalogy 95:254-268.

López-González, C., D. F. García-Mendoza, J. C. López-Vidal, AND C. Elizalde-Arellano. 2019. Multiple lines of evidence reveal a composite of species in the plateau mouse, Peromyscus melanophrys (Rodentia, Cricetidae). Journal of Mammalogy 100:1583-1598.

Lorenzo, C., S. T. Álvarez-Castañeda, S. Pérez, and J. L. Patton. 2016. Revision of the taxonomy of the Chiapan deer mouse, Peromyscus zarhynchus, with the description of a new species. Journal of Mammalogy 97:910-918.

MadDISON, W. P, AND D. R. MadDIson. 2011. Mesquite: a modular system for evolutionary analysis. Version 2.75. http://mesquiteproject.org (Accessed July 2019).

Mammal Diversity Database. 2020. Mammal Diversity Database (Version 1.31) [Data set]. Zenodo. http://doi.org/10.5281/zenodo.4139818 (Accessed January 2021).

Merriam, C. H. 1898. Description of twenty new species and a new subgenus of Peromyscus from Mexico and Guatemala. Proceedings of the Biological Society of Washington 12:115-125.

Miller, J. R., And M. D. Engstrom. 2008. The relationships of major lineages within Peromyscine rodents: A molecular phylogenetic hypothesis and systematic reappraisal. Journal of Mammalogy 89:1279-1295.

Miller, M. A., W. Pfeiffer, and T. Schwartz. 2010. Creating the CIPRES Science Gateway for inference of large phylogenetic trees. Pp. 1-8, in Proceeding of the Gateway Computing Environments Workshop (GCE), 14 November 2010. New Orleans, U.S.A. Musser, G. G. 1969. Notes on Peromyscus (Muridae) of Mexico and Central America. American Museum Novitates 2357:1-23.

Musser, G. G., And M. D. Carleton. 1993. Family Muridae. Pp. 501-755, in Mammal Species of the World, a Taxonomic and Geographic Reference (Wilson, D. E., and D. M. Reeder, eds.) second edition. Smithsonian Institution Press. Washington, U.S.A.

Musser, G. G., And M. D. Carleton. 2005. Family Muridae. Pp. 894-1531, in Mammal Species of the World, a Taxonomic and Geographic Reference (Wilson, D. E, and D. M Reeder, eds.) third edition. Johns Hopkins Press. Baltimore, U.S.A.

Ordóñez-Garza, N., ANd R. D. Bradley. 2018. Diversifícation patterns of cricetid rodents in Mesoamerica. Pp. 30-39, in Perspectivas de Investigación sobre los Mamíferos Silvestres de Guatemala (Kraker, C., A. P. Calderón, and A. A. Cabreras, eds.). Asociación Guatemalteca de Mastzoologos. Guatemala City, Guatemala.

Ordóñez-Garza, N., C. W. Thompson, M. K. Unkefer, C. W. Edwards, J. G. Owens, and R. D. Bradley. 2014. Systematics of the Neotoma mexicanus group (Mammalia: Rodentia: Cricetidae) in Mesoamerica: new molecular evidence on the status and relationship of $N$. ferruginea Tomes, 1862. Proceedings of the Biological Society of Washington 127:518-532.

Osgood, W. H. 1904. Thirty new mice of the genus Peromyscus from Mexico and Guatemala. Proceedings of the Biological Society of Washington 17:55-77

Osgood, W. H. 1909. Revision of the mice of the American genus Peromyscus. North American Fauna 28:1-285. 
Pardiñas, U. F. J., P. Myers, L. León-Paniagua, N. Ordóñez Garza, J. A. Cook, B. Kryštufek, R. Haslauuer, R. D. Bradley, G. I. ShenBRot, AND J. L. Patton. 2017. Family Cricetidae (true hamsters, voles, lemmings, New World rats and mice). Pp. 204-535, in Handbook of the Mammals of the World, Volume 7, Rodents II (Wilson, D. E., T. E. Lacher, Jr., and R. A. Mittermeier, eds.). Lynx Edicions. Barcelona, Spain.

Patton, J. L., And C. J. Conroy. 2017. The conundrum of subspecies: morphological diversity among desert populations of the California vole (Microtus californicus, Cricetidae). Journal of Mammalogy 98:1010-1026.

Pérez-Consuegra, S. G., And E. Vázquez-Domínquez. 2015. Mitochondrial diversification of the Peromyscus mexicanus species group in nuclear Central America: biogeographic and taxonomic implications. Journal of Zoological Systematics and Evolutionary Research 53:300-311.

Platt, R. N., A. M. Amman, M. S. Keith, C. W. Thompson, and R. D. Bradley. 2015. What is Peromyscus? Evidence from nuclear and mitochondrial DNA sequences suggests the need for a new classification. Journal of Mammalogy 96:708-719.

Rambaut, A., M. A. Suchard, D. Xie, and A. J. Drummond. 2014. Tracer v1.6. http://beast.bio.ed.ac.uk/Tracer

Reeder, S. A, And R. D Bradley. 2007. Phylogenetic relationships of Neotomine-Peromyscine rodents using DNA sequences from beta fibrinogen and cytochrome $b$. Pp. 883-900, in The Quintessential Naturalist: Honoring the Life and Legacy of Oliver P. Pearson (Kelt, D. A., E. P. Lessa, J. Salazar-Bravo, and J. L. Patton eds.). University of California Publications in Zoology 134:1-981.

Ronquist, F., ANd J. P. HuelsenbeCK. 2003. MRBAYES 3: Bayesian phylogenetic inference under mixed models. Bioinformatics 19:1572-574.

SaAsa, N., C. Sánchez-Hernández, M. de Lourdes Romero-Almaraz, E. Guerrero-Ibarra, A. Almazán-Catalán, H. Yoshida, D. Miyashita, M. Ishizuka, T. Sanada, T. Seto, K. Yoshi, C. Ramos, K. Yoshimatsu, J .Arikawa, I. Takashima, and H. Kariwa. 2012. Ecology of hantaviruses in Mexico: genetic identification of rodent host species and spillover infection. Virus Research 168:88-96.

Saltou, N., AND M. Nel. 1987. The neighbor-joining method: a new method for reconstructing phylogenetic trees. Molecular Biology and Evolution 4:406-425.

Sánchez-Cordero, V., ANd B. Villa-Ramírez. 1988. Variación morfométrica en Peromyscus spicilegus (Rodentia: Cricetinae) en la parte nordeste de Jalisco, México. Anales Instituto de Biología, Serie Zoología 2:819-836.

Saussure, M. H. 1860. Note sur quelques mammiféres de Mexique. Revue et Magazine Zoologie, Paris, Serie 2 12:97-110.

Sмıтн, S. A. 1990. Cytosystematic evidence against monophyly of the Peromyscus boylii species group (Rodentia: Cricetidae). Journal of Mammalogy 71:603-608.

Smith, S. A., I. F. Greenbaum, D. J. Schmidly, K. M. Davis, and T. W. Houseal. 1989. Additional notes on karyotypic variation in the Peromyscus boylii species group. Journal of Mammalogy 70:603-608.

Stamatakis, A. 2014. RAxML Version 8: A tool for phylogenetic analysis and post-analysis of large phylogenies. Bioinformatics 30:1312-1313.

Sullivan, J., ANd C. W. Kilpatrick. 1991. Biochemical systematics of the Peromyscus aztecus assemblage. Journal of Mammalogy 72:681-696.
Sullivan J., E. Arellano, and D. S. Rogers. 2000. Comparative phylogeography of Mesoamerican highland rodents: concerted versus independent response to past climatic fluctuations. The American Naturalist 155:755-768.

Sullivan, J, J. A. Market, And C. W. Kilpatrick. 1997. Phylogeographic and molecular systematics of the Peromyscus aztecus species group (Rodentia: Muridae) inferred using parsimony and likelihood. Systematic Biology 46:426-440.

Sullivan, K. A. M., R. N. Platt II, R. D. Bradley, and D. A. Ray. 2017. Whole mitochondrial genomes provide increased resolution and indicate paraphyly in deer mice. BMC Zoology 2:11.

Tiemann-Boege, I., C. W. Kilpatrick, D. J. Schmidly, and R. D. BradLEY. 2000. Molecular phylogenetics of the Peromyscus boylii species group (Rodentia: Muridae) based on mitochondrial cytochrome $b$ sequences. Molecular Phylogenetics and Evolution 16:366-378.

Thompson, J. D., D. G. Higgins, AND T. J. GiBson. 1994. CLUSTAL W: improving the sensitivity of progressive multiple sequence alignments through sequence weighting, positionsspecific gap penalties and weight matrix choice. Nucleic Acids Research 22:4673-4680.

Associated editor: Lisa and Robert Bradley Submitted: January 29, 2021; Reviewed: March 8, 2021 Accepted: April 13, 2021;Published on line:May 28, 2021. 


\section{Appendix 1}

Measurements from specimens of $P$. winkelmanni housed in the TCWC at Texas A\&M University. Body measurements include total length (TL), length of tail (LT), hind foot (HF), ear height $(\mathrm{EH})$ and cranial measurement of skull greatest length (SGL), rostral length $(R L)$, brain case width $(B C W)$, zygomatic breadth (ZB), interorbital width (IOW), molar row length (MRL), and palatal breadth (PB).

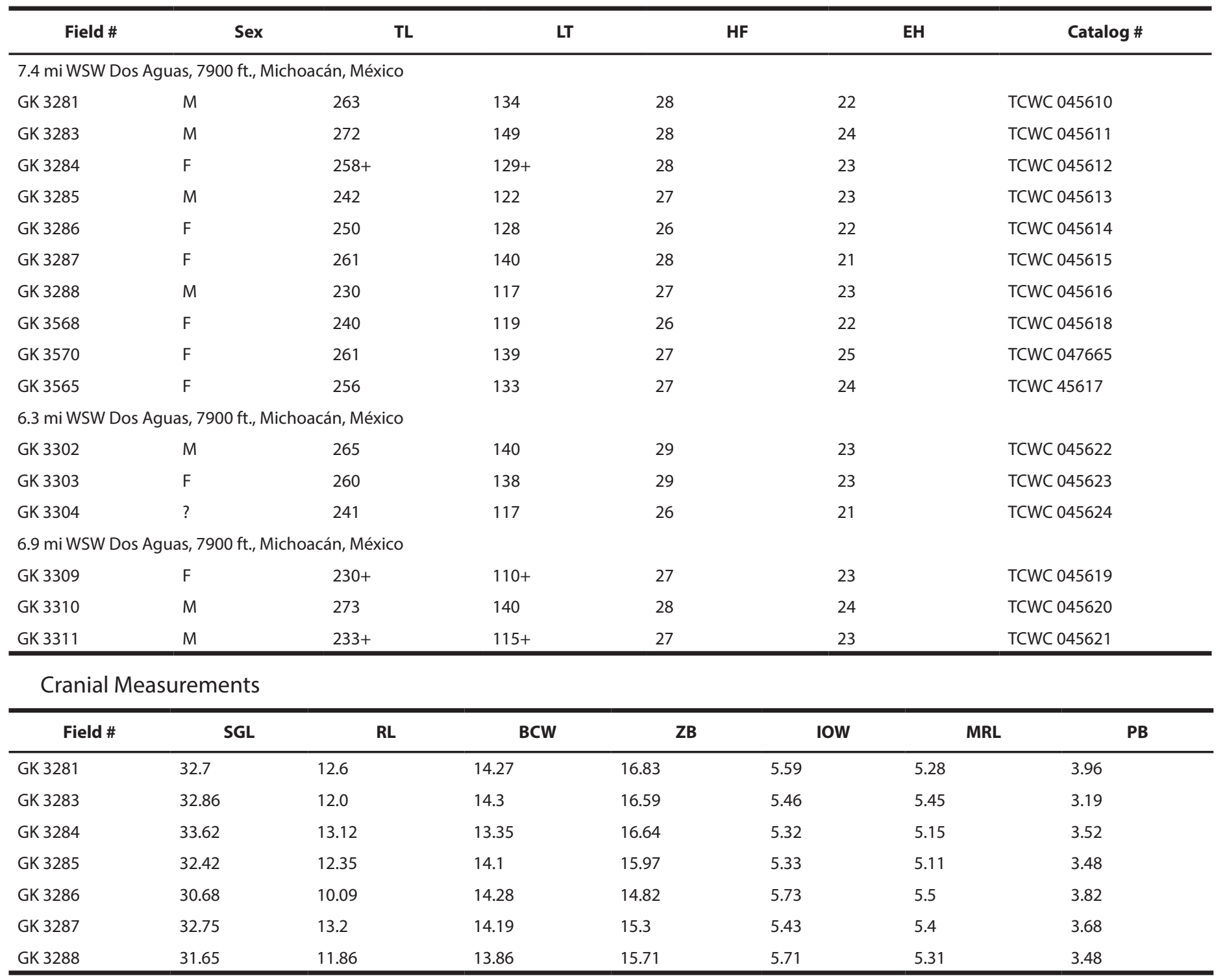

